\title{
GABRIELE GIANNINI, Un guide français de Terre sainte, entre Orient latin et Toscane occidentale
}

\section{G. Matteo Roccati}

\section{CpenEdition}

\section{Journals}

\section{Édition électronique}

URL : https://journals.openedition.org/studifrancesi/12408

DOI : $10.4000 /$ studifrancesi. 12408

ISSN : 2427-5856

\section{Éditeur}

Rosenberg \& Sellier

\section{Édition imprimée}

Date de publication : 1 avril 2018

Pagination : 107-108

ISSN : 0039-2944

\section{Référence électronique}

G. Matteo Roccati, « GABRIELE GIANNINI, Un quide français de Terre sainte, entre Orient latin et Toscane occidentale », Studi Francesi [En ligne], 184 (LXII | I) | 2018, mis en ligne le 04 juillet 2018, consulté le 16 novembre 2021. URL : http://journals.openedition.org/studifrancesi/12408 ; DOI : https://doi.org/ 10.4000/studifrancesi.12408

Ce document a été généré automatiquement le 16 novembre 2021.

\section{(c) (i) (9)}

Studi Francesi è distribuita con Licenza Creative Commons Attribuzione - Non commerciale - Non opere derivate 4.0 Internazionale. 


\title{
GABRIELE GIANNINI, Un guide français de Terre sainte, entre Orient latin et Toscane occidentale
}

\author{
G. Matteo Roccati
}

\section{RÉFÉRENCE}

GABRIELE GIANNINI, Un guide français de Terre sainte, entre Orient latin et Toscane occidentale, Paris, Classiques Garnier, 2016, « Recherches littéraires médiévales» 21, 352 pp.

1 Le guide est assez court : il est transcrit dans les ff. 173r-174r du ms. Ferrara, Biblioteca Comunale Ariostea, II.280, manuscrit contenant aussi une copie du Tresor de Brunetto Latini. Ce volume relativement épais donne l'édition du texte, surtout, il situe ce dernier à l'intérieur d'un groupe de guides latins et vernaculaires apparentés. En plus de celui de Ferrare - qui appartient à « un vaste ensemble de manuscrits exécutés entre Gênes et Pise à la fin du XIII ${ }^{\mathrm{e}}$ siècle» (p. 23) -, les manuscrits examinés sont les suivants : Bruxelles, Bibliothèque royale de Belgique, IV 1005; Città del Vaticano, Biblioteca Apostolica Vaticana, Vat. lat. 3136; Paris, B.n.F., fr. 9082 ; Wien, Österreichische Nationalbibliothek, Cod. 2590 ; Cambridge, University Library, Gg.6.28 (pp. 11-159). Pour chacun sont détaillés l'histoire, la structure et le contenu, le contexte de production, l'écriture et la décoration. Certains textes inédits ou significatifs, surtout au point de vue de la scripta, éventuellement ajoutés dans les feuillets inutilisés, sont édités et étudiés aussi. Quelques pages de synthèse et ensuite l'étude de la tradition (pp. 137-159) présentent ce groupe de guides qui dépendent de manière plus ou moins lâche d'une source commune latine rédigée au Levant et traduite en français, datable entre 1219-1220 et 1260 environ (cf. p. 154). Est examinée ensuite la scripta du Tresor et du Guide et le contexte socio-culturel dans lequel le manuscrit de Ferrare a été produit et utilisé (pp. 161-205). L'édition du Guide (pp. 209-212) est accompagnée de notes (pp. 
213-249), ainsi que celle de trois autres guides français apparentés (pp. 251-326). Bibliographie, glossaire et index des noms propres aux pp. 327-337, 339-345 et 347-349. 